\title{
Modelling plant yield and quality response of fresh-market spinach (Spinacia oleracea L.) to mineral nitrogen availability in the root zone
}

\author{
Daniele Massa, ${ }_{1}$ Luca Incrocci, ${ }^{2}$ Luca Botrini, ${ }^{2}$ Giulia Carmassi, ${ }^{2}$ Cecilia Diara, ${ }^{2}$ \\ Pasquale Delli Paoli, ${ }^{3}$ Giorgio Incrocci, ${ }^{2}$ Rita Maggini, ${ }^{2}$ Alberto Pardossi ${ }^{2}$ \\ ${ }^{1}$ CREA Research Centre for Vegetable and Ornamental Crops, Council for Agricultural Research and \\ Economics, Pescia (PT); ${ }^{2}$ Department of Agriculture, Food and Environment, University of Pisa, Pisa; \\ ${ }^{3}$ Coop Agricoltura 2000, Venturina (LI), Italy
}

\begin{abstract}
Spinach is one of the most important green-leafy vegetables, consumed worldwide, and its intake is beneficial for human beings. In this crop, produce yield and quality are closely related to plant nitrogen $(\mathrm{N})$ nutrition. A precise supply of $\mathrm{N}$ is also essential for high environmental and economic sustainability. Main aims of the work were: i) to establish relationships between produce yield or quality and mineral $\mathrm{N}$ availability in the root zone; and ii) to define an optimal mineral $\mathrm{N}$ level to be maintained in the root zone for spinach. Eight experiments were carried out during a four-year-long period under typical Mediterranean climate conditions. Different amounts of $\mathrm{N}$ fertilisers were supplied leading to twenty different levels of mineral $\mathrm{N}$ in the root zone. Experimental measurements included climate parameters, plant growth, tissue and soil analyses, produce yield and quality indicators. A segmented linear model significantly represented the relationship between crop yield (1.7 to $21.7 \mathrm{tha}^{-1}$ ) and soil mineral $\mathrm{N}$ concentration (7.6 to $41.0 \mathrm{mg} \mathrm{kg}^{-1}$ ). Basing on this model, an optimal mineral $\mathrm{N}$
\end{abstract}

Correspondence: Daniele Massa, CREA Research Centre for Vegetable and Ornamental Crops, Council for Agricultural Research and Economics, via dei Fiori 8, 51012 Pescia (PT), Italy.

Tel.: +39.0572.451033 - Fax: +39.0572.453309.

E-mail: daniele.massa@crea.gov.it

Key words: Fertilisation; leaf nitrates; leafy vegetable; nitrogen nutrition index; photothermal units; SPAD index.

Acknowledgements: this work was carried out with funds from the Ministry of Agricultural, Food and Forestry Policies (Decree N. 25279 of 23 December 2003) as part of the AZORT project. The authors are also grateful to Prof. A. Ferrante for his support in the revision of the paper.

Received for publication: 30 September 2017.

Revision received: 17 February 2018.

Accepted for publication: 19 February 2018.

(C) Copyright D. Massa et al., 2018

Licensee PAGEPress, Italy

Italian Journal of Agronomy 2018; 13:1120

doi:10.4081/ija.2018.1120

This article is distributed under the terms of the Creative Commons Attribution Noncommercial License (by-nc 4.0) which permits any noncommercial use, distribution, and reproduction in any medium, provided the original author(s) and source are credited. threshold was fixed at $23.4 \mathrm{mg} \mathrm{kg}^{-1}$. Above this threshold, crop yield did not show any significant variations as well as tissue characteristics and produce quality. Plants grown under suboptimal $\mathrm{N}$ levels showed reduction in growth, tissue mineral (nutrients) content, and SPAD index. The proposed models could be implemented in fertilisation protocols for the optimization of $\mathrm{N}$ supply and the estimation of spinach growth and yield.

\section{Introduction}

In the Mediterranean basin, savoy spinach (Spinacia oleracea L.) represents an important typical produce exported in many countries of northern Europe. For fresh market, savoy spinach is harvested at early growth stage. The most important quality attributes of this leafy vegetable are related to the leaf greenness and morphology (i.e., wrinkledness), to the content of beneficial mineral elements, and to the low content of toxic compounds such as oxalic acid and nitrates (Santamaria et al., 1999; Cavaiuolo and Ferrante, 2014).

Well-balanced nitrogen (N) supply is crucial for high yield and market quality of spinach. Many authors reported a positive relationship between crop yield and increasing $\mathrm{N}$ fertiliser rate in spinach cultivated in open field or under greenhouse (Biemond et al., 1996; Wang and Li, 2004; Gülser, 2005; Lefsrud et al., 2007; Stagnari et al., 2007; Rodriguez-Hidalgo et al., 2010). The spinach content in mineral elements and antioxidants, such as lutein and $\beta$-carotene, are both positively related to $\mathrm{N}$ availability (Lefsrud et al., 2007; Stagnari et al., 2007).

On the other hand, $\mathrm{N}$ excess may lead to large leaf accumulation of oxalic acid and nitrates in leaf tissues, especially when $\mathrm{N}$ is supplied in the nitric form (Chen et al., 2004; Wang and Li, 2004; Zhang et al., 2005; Stagnari et al., 2007). Similarly to nitrates, oxalic acid and related compounds are harmful molecules for human beings and their continuous intake can induce blood diseases, especially in infants, nutritional disorders, and other health disturbs in human body (Noonan, 1999; Bryan and Loscalzo, 2011; Agnoli et al., 2017). In the European Union (EU) specific limits have been laid down for the nitrate content of some leafy vegetables (The Council of the European Community, 2006; EFSA, 2008). In spinach, these limits are 2000 and $3500 \mathrm{mg} \mathrm{NO}_{3}{ }^{-} \mathrm{kg}^{-1}$ (fresh weight basis) for frozen and fresh products, respectively.

Excessive $\mathrm{N}$ supply also results in increased water content of leaf tissues (Lefsrud et al., 2007), which may negatively influence plant resistance to pathogens (Dordas, 2008) and its shelf life as well (Lombardo et al., 2016). A correct $\mathrm{N}$ fertiliser management is essential for reducing the crop environmental impact associated with nitrate leaching (Robertson and Vitousek, 2009; Zhou and 
Butterbach-Bahl, 2014), which easily occurs in sandy soils where spinach is typically cultivated. In the EU, the Nitrates Directive (The Council of the European Communities, 1991) was issued to preserve the quality of ground and surface water bodies from the pollution of nitrates produced by agricultural activity, and to promote the adoption of good agricultural practices. According to the Nitrates Directive, growers must follow mandatory rules to tackle nitrate loss from their crops; for example, in the area of Val di Cornia (Tuscany, Italy), where the experiment took place, a maximum $\mathrm{N}$ dose of $120 \mathrm{~kg} \mathrm{ha}^{-1}$ and well defined (limited) periods of distribution have been ruled for spinach by the local authorities.

Moreover, $\mathrm{N}$ waste has negative economic impact on the production costs of field crops (Robertson and Vitousek, 2009). Some authors have related crop yield and $\mathrm{N}$ supply to economic parameters, to calculate the $\mathrm{N}$ fertiliser rate that maximizes grower's incomes (Wang and Li, 2004; Milne et al., 2012).

Literature on leafy vegetables mostly focuses on the effects of $\mathrm{N}$ on yield and quality (Chen et al., 2004; Wang and Li, 2004; Zhang et al., 2005; Lefsrud et al., 2007; Stagnari et al., 2007) while less attention is paid to effective $\mathrm{N}$ management (Canali et al., 2014).

However, most works attempt to describe growth and yield response curves as a function of fertiliser doses instead of the actual $\mathrm{N}$ availability in the root zone. For optimal $\mathrm{N}$ management different authors have therefore introduced the concept of minimum optimal concentration (Heckman et al., 2002; Cui et al., 2008; Bottoms et al., 2012); this would represent the reference value to be maintained in the root zone to minimize crop environmental impact and to support high yield and quality (Incrocci et al., 2017). To the best of our knowledge, no previous study addresses the above issue for spinach, thus an $\mathrm{N}$ optimal concentration for this crop has not been yet determined.

The paper reports experimental data collected in eight different experiments carried out during a four-year-long period. Main aims of the work are: i) to assess the effects of soil $\mathrm{N}$ concentration on spinach yield and quality throughout a medium-long observation period under different climate conditions; ii) to define an optimal soil mineral $\mathrm{N}$ concentration for effective $\mathrm{N}$ management; and iii) to test an optical sensor for the quick monitoring of $\mathrm{N}$ nutritional status in fresh-market spinach grown under open-field Mediterranean climate conditions.

\section{Materials and methods}

\section{Growing conditions and treatments}

Experimental data were collected in eight different experiments (E), on spinach (Spinacia oleracea L.) crops, during a fouryear-long period (from September 2007 to April 2011). Experimental fields were located in Val di Cornia (Tuscany, Italy), a coastal area with sandy-loam soils. The area is intensively cultivated with vegetables under typical Mediterranean climate conditions (Figure 1) with mild winters and $650 \mathrm{~mm}$ annual rainfall (tenyear average).

The physico-chemical characteristics of the soil (Table 1) were determined in the root zone of spinach $(5-40 \mathrm{~cm})$ prior to sowing. The quantity of fertilisers containing $\mathrm{P}, \mathrm{K}, \mathrm{Ca}, \mathrm{Mg}$ and micronutrients was then calculated through a soil nutrient balance aimed to: i) replace the nutrients taken up by a crop grown under optimal conditions; and ii) restore the initial soil fertility if necessary. Only $\mathrm{N}$ was supplied in a variety of different doses (Table 2) based on the following criteria. During the first two experiments (E1 and E2), $\mathrm{N}$ was supplied at the fixed rate of $0,80,120$ or $160 \mathrm{~kg} \mathrm{ha}^{-1}$. In the other experiments (E3-E8), $\mathrm{N}$ was supplied following growers' fertilisation practice. This is based on the standard fertilisation rate of $120 \mathrm{~kg} \mathrm{~N} \mathrm{ha}^{-1}$, according to the blueprint laid down for spinach production in the Val di Cornia area. The above quantity is usually increased by growers up to $175 \mathrm{~kg} \mathrm{ha}^{-1}$ in relation to the rainfalls occurred in the growing period, which may increase the risk for $\mathrm{N}$ shortage due to nitrate leaching. Each experiment always

Table 1. Chemical and physical characteristics in the $0-40 \mathrm{~cm}$ depth layer of the different experimental fields ( $\mathrm{n}=8$ ) used for spinach cultivation.

\begin{tabular}{|c|c|c|c|c|c|}
\hline Parameter & Maximum value & Minimum value & Average & SD & CV \\
\hline Sand (\%) & 76.1 & 58.6 & 69.1 & 6.4 & 0.1 \\
\hline Silt (\%) & 19.8 & 10.8 & 15.4 & 3.1 & 0.2 \\
\hline Clay (\%) & 26.0 & 7.8 & 15.5 & 5.6 & 0.4 \\
\hline Bulk density $\left(\mathrm{t} \mathrm{m}^{-3}\right)$ & 1.48 & 1.40 & 1.45 & 0.3 & 0.3 \\
\hline Field capacity $(\%, v / v)$ & 26.7 & 13.2 & 18.4 & 4.5 & 0.2 \\
\hline Wilting point $(\%, v / v)$ & 16.7 & 5.7 & 10.3 & 3.5 & 0.3 \\
\hline Organic matter (\%) & 2.1 & 1.0 & 1.4 & 0.4 & 0.1 \\
\hline Total N (mg kg-1) & 800.0 & 700.0 & 757.1 & 53.5 & 0.4 \\
\hline $\mathrm{N}-\mathrm{NO}_{3}{ }^{-}\left(\mathrm{mg} \mathrm{kg}^{-1}\right)$ & 19.7 & 3.6 & 13.2 & 5.0 & 0.4 \\
\hline $\mathrm{N}-\mathrm{NH}_{4}{ }^{+}\left(\mathrm{mg} \mathrm{kg}^{-1}\right)$ & 11.3 & 3.6 & 7.3 & 2.9 & 0.4 \\
\hline $\mathrm{P}_{2} \mathrm{O}_{5}\left(\mathrm{mg} \mathrm{kg}^{-1}\right)$ & 109.0 & 37.0 & 73.4 & 27.1 & 0.3 \\
\hline $\mathrm{K}_{2} \mathrm{O}\left(\mathrm{mg} \mathrm{kg}^{-1}\right)$ & 235.0 & 110.0 & 187.2 & 48.2 & 0.4 \\
\hline $\mathrm{CaO}\left(\mathrm{mg} \mathrm{kg}^{-1}\right)$ & 3190.0 & 1451.0 & 1946.0 & 711.3 & 0.3 \\
\hline $\operatorname{MgO}\left(\mathrm{mg} \mathrm{kg}^{-1}\right)$ & 230.0 & 113.0 & 174.0 & 49.6 & 0.3 \\
\hline CEC (meq 100g $\mathrm{g}^{-1}$ ) & 18.1 & 9.2 & 12.4 & 4.0 & 0.1 \\
\hline $\mathrm{pH}\left(\mathrm{H}_{2} \mathrm{O}\right)$ & 7.8 & 6.8 & 7.4 & 0.5 & 0.3 \\
\hline $\mathrm{EC}\left(\mathrm{dS} \mathrm{m}^{-1}\right)$ & 0.7 & 0.4 & 0.5 & 0.1 & 0.1 \\
\hline
\end{tabular}


included a dose of $\mathrm{N}$ equal to 0 as untreated control (Table 2). In all treatments, the total amount of $\mathrm{N}$ was split over three periods: i) $40 \%$ blended with the soil, before sowing (4-6 days), using a mixed organic-mineral fertiliser (1\% organic, 5\% ammonia and $30 \%$ ureic); ii) $30 \%$ distributed as top-dressing fertilisation, at $1 / 3$ of the cultivation cycle (roughly 4-5 true leaves), using ammonium nitrate; iii) $30 \%$ distributed as top-dressing fertilisation, at $2 / 3$ of the cultivation cycle (roughly 10-11 true leaves), using calcium nitrate. In the case of rainy periods (i.e., when total rainfall in the 8-14 true-leaf phase was 50\% higher than the average of the previous ten years), with high $\mathrm{N}$ leaching, a third top-dressing fertilisation (40-50 $\mathrm{kg} \mathrm{N} \mathrm{ha}^{-1}$ ) was applied when spinach had 14-15 true leaves (E3, E4 and E8).

Soil preparation of seedbed included ploughing, harrowing and levelling for bringing the soil into the better tilt for water drainage. Spinach (cv. Spitfire, Seminis ${ }^{\circledR}$, Monsanto Company, USA) was sown in order to have a plant density of 30 plants $\mathrm{m}^{-2}$ taking into account the percentage of emergency. Each treatment was applied in a completely randomized experimental design on an area of $800-1000 \mathrm{~m}^{2}$.

Irrigation was applied rarely (only once at germination in E1 and E3), using traveling sprinklers, to restore the field capacity when rainfall events were not sufficient to preserve the quantity of easily available water (50-60\% of the available water) in the root zone (Table 1). Soil moisture was monitored by using a tensiometer (Delta-T SWT 4, Delta-T Device Ltd, Cambridge UK) with the ceramic cup positioned within $20-30 \mathrm{~cm}$ depth in the driest area of the field. Crop protection was accomplished following the standard protocol used by local growers that includes treatment against insects, fungi and weeds.

Climate parameters were monitored hourly using a meteorological station (Pessl Instruments GmbH, Weiz, Austria) located in the experimental area. Air and soil temperature, radiation, wind speed, rainfall and air humidity data were collected and summarized in Figure 1 and Table 2.

\section{Plant and soil analysis}

Plant samples were collected at different crop stages, i.e., at: i) 4-5 true leaves; ii) 10-11 true leaves; and iii) harvest time; for each treatment, three replicates were collected in the first and second sampling, and four replicates at harvest. Each replication unit con- sisted of an area of $3.5 \mathrm{~m}^{2}$ that corresponded roughly to 100 plants. Sample units were collected randomly in each treatment. Plants were harvested by hand, stored in plastic bags to limit water loss, and moved rapidly to the laboratory for growth and tissue analyses. The growth analysis consisted in the measurement of fresh (FW) and dry weight (DW, obtained in a forced-air oven at $80^{\circ} \mathrm{C}$ for 96 h), number of true leaves, and leaf area, determined by a planimeter (Delta-T Device, Cambridge, UK) for the calculation of leaf area index. Leaf chlorophyll was assessed through SPAD index (SPAD-502, Konica Minolta Optics, 2970 Ishikawa-machi, Hachioji, Tokyo, Japan). Plant dry matter was analysed for its mineral nutrient content. In more detail, total $\mathrm{N}$ was determined as the sum of reduced $\mathrm{N}$ (by the Kjeldhal method) and $\mathrm{N}-\mathrm{NO}_{3}$; the latter was determined in the aqueous extract of dry matter $(1: 300, \mathrm{w} / \mathrm{w})$ using a colorimetric method (Cataldo et al., 1975). After nitric-perchloric acid digestion of dried samples $\left(90 \mathrm{~min}\right.$ at $\left.150^{\circ} \mathrm{C}\right), \mathrm{K}, \mathrm{Ca}$, and $\mathrm{Mg}$ were determined by atomic absorption spectroscopy (Spectra-AA240 FS, Varian, Australia), while P was measured through a colorimetric method (Olsen and Sommers, 1982).

In occasion of plant destructive analyses, soil samples were also collected in each replication unit and analysed for mineral $\mathrm{N}$ content $\left(\mathrm{N}_{\min }\right)$. Nitrate was measured in the aqueous extract of dry soil (soil-water ratio 1:2 w/w) using the Cataldo's method (1975). Ammonium was extracted from soil using $1 \mathrm{M} \mathrm{KCl}$ (soil- $\mathrm{KCl}$ ratio $1: 2 \mathrm{w} / \mathrm{w})$ and quantified spectrophotometrically through the indophenol method (Kempers and Kok, 1989).

\section{Data analysis and modelling}

Most of the variables analysed in the work refer to the averaged concentration of total $\left(\mathrm{N}-\mathrm{NH}_{4}^{+}\right.$plus $\left.\mathrm{N}^{+} \mathrm{NO}_{3}^{-}\right)$mineral $\mathrm{N}$ $\left(\mathrm{N}_{\min }\right)$ in the root zone. Nitrogen concentration in this work is mostly expressed as mg of element per kg of dry soil. The conversion from $\mathrm{mg} \mathrm{kg}^{-1} \mathrm{~N}$ to $\mathrm{N}$ expressed as $\mathrm{kg}$ per hectare can be computed using the following equation:

$\mathrm{N}_{\min }\left(\mathrm{kg} \mathrm{ha}^{-1}\right)=\mathrm{N}_{\min }\left(\mathrm{mg} \mathrm{kg}^{-1}\right) \cdot \mathrm{BD} \cdot \mathrm{RD} \cdot 10$

where $\mathrm{BD}$ is the soil bulk density $\left(1.45 \mathrm{t} \mathrm{m}^{-3}\right.$, on average; Table 1$)$, $\mathrm{RD}$ is the root depth $(0.40 \mathrm{~m})$, and 10 is a multiplicative factor for unit conversion (from mg kg-1 to $\mathrm{kg} \mathrm{ha}^{-1}$ ); then in our growing

Table 2. Period of cultivation (dates), experiment duration (days after sowing, DAS), and nominal doses of $\mathrm{N}$ supplied in each experiment (E) are reported in the table as single values. Mean air temperature (Ta), growing degree days (GDD), mean and cumulative daily global radiation ( $\mathrm{Rad}$ and Cum. Rad, respectively), photothermal units (PTU) and cumulative rainfall (Rain) recorded in each experiment (E).

\begin{tabular}{|c|c|c|c|c|c|c|c|c|c|c|}
\hline Experiment & Sowing & Harvest & DAS & $\begin{array}{c}\text { Dose of } \mathrm{N} \text { applied } \\
\left(\mathrm{kg} \mathrm{ha}^{-1}\right)\end{array}$ & $\begin{array}{c}\mathrm{Ta} \\
\left({ }^{\circ} \mathrm{C}\right)\end{array}$ & $\begin{array}{l}\text { GDD } \\
\left({ }^{\circ} \mathrm{C}\right)\end{array}$ & $\begin{array}{c}\text { Rad } \\
\left(\mathrm{MJ} \mathrm{m}^{-2} \text { day }^{-1}\right)\end{array}$ & $\begin{array}{l}\text { Cum. Rad } \\
\left(\mathrm{MJ} \mathrm{m}^{-2}\right)\end{array}$ & $\begin{array}{c}\text { PIU } \\
\left({ }^{\circ} \mathrm{C} \mathrm{MJ} \mathrm{m}^{-2}\right)\end{array}$ & $\begin{array}{l}\text { Rain } \\
(\mathrm{mm})\end{array}$ \\
\hline E1 & $01 / 10 / 2007$ & 07/01/2008 & 98 & $0-80-120-160$ & 11.5 & 831.3 & 6.3 & 622.1 & 3383.9 & 256.0 \\
\hline E2 & $24 / 10 / 2007$ & $25 / 02 / 2008$ & 124 & $0-80-120-160$ & 9.2 & 769.0 & 5.2 & 643.2 & 2575.8 & 369.4 \\
\hline E3 & $29 / 09 / 2008$ & 29/12/2008 & 91 & $0-160$ & 12.9 & 907.3 & 6.4 & 583.5 & 3553.7 & 649.0 \\
\hline E4 & $20 / 10 / 2008$ & 19/02/2009 & 122 & $0-155$ & 9.9 & 862.2 & 4.9 & 596.3 & 2666.0 & 829.8 \\
\hline E5 & 06/10/2009 & 29/12/2009 & 84 & $0-130$ & 12.3 & 783.7 & 7.4 & 624.3 & 2620.1 & 271.4 \\
\hline E6 & 18/11/2009 & $30 / 03 / 2010$ & 132 & $0-120$ & 9.2 & 815.3 & 8.5 & 1117.0 & 5550.3 & 485.6 \\
\hline E7 & 08/10/2010 & 10/01/2011 & 94 & $0-145$ & 11.2 & 772.0 & 5.4 & 511.4 & 2297.7 & 344.1 \\
\hline E8 & $16 / 12 / 2010$ & 04/04/2011 & 109 & $0-175$ & 9.0 & 652.6 & 8.4 & 911.7 & 4588.3 & 219.4 \\
\hline Average & - & - & - & - & 10.6 & 799.2 & 6.6 & 701.2 & 3404.5 & 428.1 \\
\hline SD & - & - & - & - & 1.5 & 75.9 & 1.4 & 204.8 & 1140.2 & 214.4 \\
\hline $\mathrm{CV}$ & - & - & - & - & 0.1 & 0.1 & 0.2 & 0.3 & 0.3 & 0.5 \\
\hline
\end{tabular}


conditions the product of $\mathrm{BD}, \mathrm{RD}$ and 10 was 5.8 .

To compare the yield $(\mathrm{Y})$ of different experiments carried out under different temperature and radiation levels (Figure 1 and Table 1) the photothermal use efficiency of each single treatment ( $\mathrm{Y}_{\mathrm{PTU}}$; mg $\mathrm{MJ}^{-1}{ }^{\circ} \mathrm{C}^{-1}$ ) was calculated according to Thornley and Johnson (1990). For each experiment, $\mathrm{Y}$ was divided by the photothermal units (PTU; $\mathrm{MJ} \mathrm{m}^{-2}{ }^{\circ} \mathrm{C}$ ) accumulated during in the growing period from the appearance of the first true leaf to harvest, (Eq. 2):

$$
\mathrm{Y}_{\mathrm{PTU}}=\frac{\mathrm{Y}}{\sum_{\mathrm{i}=1}^{\mathrm{n}} \operatorname{Rad}_{\mathrm{i}} \cdot\left(\mathrm{Ta}_{\mathrm{i}}-\mathrm{Tb}\right)}
$$

where $\operatorname{Rad}_{\mathrm{i}}$ and $\mathrm{Ta}_{\mathrm{i}}$ are the radiation and the mean air temperature measured at the $i^{\text {th }}$ day, respectively, and $\mathrm{Tb}$ represents the base temperature below which plant development does not occur. The base temperature was estimated by empirical methods, as suggested in other works (Wolfe et al., 1989; Jenni et al., 1996). Specifically, $\mathrm{Tb}$ was calculated as the value (ranging between $-4^{\circ} \mathrm{C}$ and $8^{\circ} \mathrm{C}$, with steps of $1^{\circ} \mathrm{C}$ ) that maximized the determination coefficient of the linear regression (Eq. 3) between the number of true leaves $\left(\mathrm{n}_{\text {Leaves }}\right)$ and growing degree $\left(\sum_{\mathrm{i}=1}^{\mathrm{n}}\left(\mathrm{Ta}_{\mathrm{i}}-\mathrm{Tb}\right) ; \mathrm{GDD}\right)$ :

$$
\mathrm{n}_{\text {Leaves }}=\mathrm{a}+\mathrm{b} \sum_{\mathrm{i}=1}^{\mathrm{n}}\left(\mathrm{Ta}_{\mathrm{i}}-\mathrm{Tb}\right)
$$

In our case, the best fit was obtained with the following equation, using $\mathrm{Tb}=3^{\circ} \mathrm{C}: \mathrm{n}_{\text {Leaves }}=-6.47+0.030 \cdot \mathrm{GDD},(\mathrm{n}=260$; $\left.R^{2}=0.81, \mathrm{P}<0.001\right)$.

For each experiment, normalized values of $\mathrm{Y}_{\mathrm{PTU}}\left(\mathrm{Y}^{*}{ }_{\mathrm{PTU}}\right)$ were obtained as the ratio between $\mathrm{Y}_{\mathrm{PTU}}$ and its maximum value ( $\left.\mathrm{Y}_{\mathrm{PTU}}^{\mathrm{max}}\right)$ :

$$
\mathrm{Y}_{\mathrm{PTU}}^{*}=\frac{\mathrm{Y}_{\mathrm{PTU}}}{\mathrm{Y}_{\mathrm{PTU}}^{\mathrm{MAX}}}
$$

Following the approach proposed by Magán et al. (2008), $\left(\mathrm{Y}_{\mathrm{PTU}}^{\mathrm{max}}\right)$ was represented by the average yield of those treatments that did not differ statistically (i.e., following ANOVA results) from the maximum yield obtained among all treatments.

A segmented linear-plateau model was adopted to fit normalized data of dry and fresh $\mathrm{Y}_{\mathrm{PTU}}\left(\mathrm{Y}^{*}{ }_{\mathrm{DW}}\right.$ and $\mathrm{Y}^{*}{ }_{\mathrm{FW}}$, respectively). With this model, biomass production is assumed to be zero if $\mathrm{N}_{\text {min }}$ is less than or equal to a minimum threshold value $\left(\mathrm{N}_{0}\right)$; afterward, $\mathrm{Y}$ starts to increase linearly with $\mathrm{N}_{\min }$ up to the optimal $\mathrm{N}$ concentration $\left(\mathrm{N}_{\mathrm{opt}}\right)$ that represents the level of $\mathrm{N}_{\min }$ above which $\mathrm{Y}$ reaches its maximum value (Eq. 5):

$$
\mathrm{Y}_{\mathrm{PTU}}^{*}=\left\{\begin{array}{c}
0 \text { if } \mathrm{N}_{\min } \leq \mathrm{N}_{0} \\
\mathrm{a}+\mathrm{b} \cdot \mathrm{N}_{\min } \text { if } \mathrm{N}_{0}<\mathrm{N}_{\min }<\mathrm{N}_{\mathrm{opt}} \\
1 \text { if } \mathrm{N}_{\min } \geq \mathrm{N}_{\mathrm{opt}}
\end{array}\right.
$$

where $\mathrm{Y}^{*}{ }_{\mathrm{PTU}}$ is the ratio $\mathrm{Y}_{\mathrm{PTU}} /\left(\mathrm{Y}_{\mathrm{PTU}}^{\max }\right)$. Following the approach proposed by Magán et al., (2008), the coefficients a and b were determined by consecutive linear regression analyses run fitting the complete group of treatments and step by step subtracting the treatments at the right of a possible $\mathrm{N}_{\text {opt }}$ threshold till achieving the highest coefficient of determination $\left(R^{2}\right)$. Finally, $\mathrm{N}_{\text {opt }}$ and $\mathrm{N}_{0}$ were obtained solving the equation $\mathrm{Y}^{*}{ }_{\mathrm{PTU}}=\mathrm{a}+\mathrm{b} \cdot \mathrm{N}_{\min }$ when $\mathrm{Y}^{*}{ }_{\mathrm{PTU}}$ was equal to 1 and 0 , respectively.
A linear model was used to describe the relationship between the N nutrition index (NNI) and the SPAD index of spinach. Both parameters were calculated by the average of data collected during the entire cultivation cycle in each treatment. The NNI was calculated as the ratio between the tissue total $\mathrm{N}$ concentration for each treatment and the tissue average $\mathrm{N}$ concentration of those treatments with optimal $\mathrm{N}_{\min }$ levels in the root zone (i.e., $\mathrm{N}_{\min } \geq \mathrm{N}_{\mathrm{opt}}$ ).

Other data (i.e., crop $\mathrm{Y}$ and $\mathrm{N}$ uptake at harvest, and tissue nutrient concentrations) were analysed through one-way ANOVA and Tukey test (HSD) for the separation of the means.

The programs Statgraphics Centurion XV (Statpoint Technologies, Inc., Warrenton, Virginia, USA) and Prism 5 (GraphPad Software, Inc., La Jolla, California, USA) were used for data analysis.

\section{Results}

\section{Growing conditions}

Figure 1 and Table 2 report the main climate variables monitored during the whole experimental period. The average values of Ta did not differ much among the different trials, showing the lowest CV as compared with other climate variables (Table 2). Mean daily Ta was used to calculate GDD (see Eq. 2 for details), which averaged $799.2^{\circ} \mathrm{C}$ among all trials, with the minimum and maximum values recorded for $\mathrm{E} 8\left(652.6^{\circ} \mathrm{C}\right)$ and $\mathrm{E} 3\left(907.3^{\circ} \mathrm{C}\right)$, respectively (Table 2).

Mean daily Rad varied more than Ta during the experiment (Table 2) with the minimum daily-averaged value recorded for E5 and E6 (0.44 $\mathrm{MJ} \mathrm{m}^{2}$ day $^{-1}$ ) in December 2009 (Figure 1), and the maximum value recorded for E6 in March 2010 (25.0 MJ m² day ${ }^{-1}$ ). The combination of Ta and Rad in Eq. 2 resulted in different PTU values that ranged between $2297.7^{\circ} \mathrm{C} \mathrm{MJ} \mathrm{m}^{-2}$ for $\mathrm{E} 7$ and $5550.3^{\circ} \mathrm{C}$ $\mathrm{MJ} \mathrm{m}^{-2}$ for E6 with an average of $3404.5^{\circ} \mathrm{C} \mathrm{MJ} \mathrm{m}^{-2}$ (Table 2).

The accumulated rainfall, among the other climate variables (Table 2), showed the highest variability with the minimum and maximum value recorded for E8 $(219.4 \mathrm{~mm})$ and E4 $(829.8 \mathrm{~mm})$, respectively. In general, rainfall events were regularly distributed during the growing seasons, excluding some exceptional precipitations above $60 \mathrm{~mm}$ day $^{-1}$ recorded for E3, E4 and E5 (Figure 1).

Due to diverse climate conditions, the duration of different crop cycles varied over the entire experimental period (Figure 1 and Table 2). The shortest culture was recorded in 2009, when E5 lasted 84 days, while the longest one (E6) was registered in 20092010 and lasted 132 days (Table 2).

The different $\mathrm{N}$ treatments (Table 2) and growing conditions produced a variety of $\mathrm{N}_{\min }$ levels in the root zone as summarized in Figure 2. Data reported in Figure 2A represent the averages of soil samples collected during the experimentation in each treatment $(5$ samplings). To evaluate the time-dependent variability of collected data, CV and SD were also calculated and averaged at each sampling time. The coefficient of variation averaged $30 \%$ and the maximum values were generally recorded for those treatments with no supply of $\mathrm{N}$ fertiliser $\left(\mathrm{N}_{0}\right)$. High $\mathrm{CV}$ values in these treatments were therefore due to high variability in $\mathrm{N}_{\min }$ that generally tended to decrease with time. This effect could mainly be related to $\mathrm{N}$ depletion in the root zone, which occurred because of the absence of $\mathrm{N}$ fertilisers supply. On the contrary, the lowest variability for $\mathrm{N}_{\min }$ concentration was observed in those treatments that underwent $\mathrm{N}$ fertilisations and scarce rainfall with limited $\mathrm{N}-\mathrm{NO}_{3}{ }^{-}$leaching. However, the different experiments differed significantly 
(ANOVA, $\mathrm{P}<0.001$ ) for the actual mean values of $\mathrm{N}_{-} \mathrm{NO}_{3}{ }^{-}, \mathrm{N}_{-} \mathrm{NH}_{4}{ }^{+}$ and as a consequence $\mathrm{N}_{\min }$ concentration in the root zone (Figure 2A); the latter ranged from 7.6 to $41.0 \mathrm{mg} \mathrm{kg}^{-1}$ that corresponded to 44.3 and $237.6 \mathrm{~kg} \mathrm{ha}^{-1} \mathrm{~N}_{\min }$ available in the soil profile explored by the root system (see Eq. 1 for conversion coefficients). Mineral
$\mathrm{N}$ was strongly correlated to the concentration of $\mathrm{N}^{-\mathrm{NO}_{3}-}(R=1.00$, $\mathrm{n}=300, \mathrm{P}<0.001$ ), which accounted for roughly $81 \% \mathrm{~N}_{\min }$ on the average of all treatments. A significant albeit weak correlation was also found between $\mathrm{N}-\mathrm{NH}_{4}{ }^{+}$and $\mathrm{N}_{\min }(R=0.49, \mathrm{n}=300, \mathrm{P}=0.02)$.

On the other hand, it appears crucial to highlight that a very
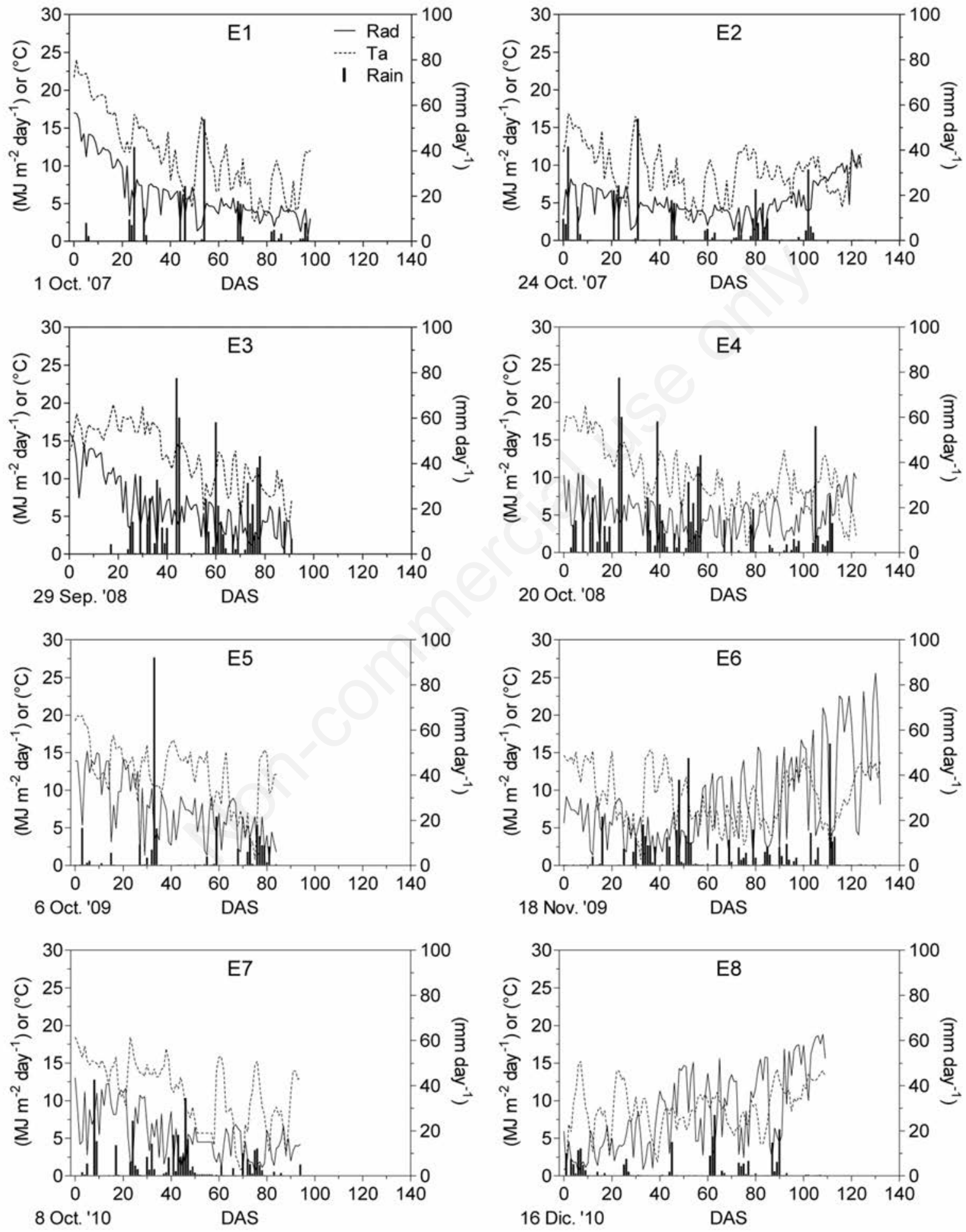

Figure 1. Daily global radiation ( $\mathrm{Rad}, \mathrm{MJ} \mathrm{m}^{-2}$ day $\left.^{-1}\right)$, mean air temperature $\left(\mathrm{Ta},{ }^{\circ} \mathrm{C}\right)$ and rainfall (Rain, mm) plotted versus days after sowing (DAS) in the different experiments (E, see Table 2 for details). The date reported below 0 represents the sowing date. 
poor relationship was instead found between the actual $\mathrm{N}_{\min }$ and the nominal $\mathrm{N}$ dose supplied by fertilisers (Figure 2B).

\section{Biomass accumulation and biometric parameters}

At harvest, plant DW and FW significantly varied among treatments (Table 3). The dry weight accumulated in the aboveground biomass ranged between 0.25 (E6-0) and 2.43 (E1-160) t ha ${ }^{-1}$ while FW varied from 1.72 (E6-0) to 21.69 (E1-120) $\mathrm{t} \mathrm{ha}^{-1}$.

Leaf area index ranged between 0.3 and 2.3 and was significantly correlated to both the accumulated DW $(R=0.75, \mathrm{n}=80$, $\mathrm{P}<0.001)$ and FW $(R=0.71, \mathrm{n}=80, \mathrm{P}<0.001)$. Similar results were also found for the total $\mathrm{N}$ uptake calculated on a DW basis, which was significantly correlated to plant biomass accumulation at harvest $(R=0.95, \mathrm{n}=80, \mathrm{P}<0.001) ; \mathrm{N}$ uptake increased from 6.28 (E60) to $87.37 \mathrm{~kg} \mathrm{ha}^{-1}$ (E1-160) depending on treatments (Table 3 ).

Significant differences among $\mathrm{N}$ treatments were also observed for the specific leaf area that increased with $\mathrm{N}_{\min }$ availability. With respect to the thermal time (GDD), the specific leaf area significantly changed during the crop cycle, decreasing linearly from emergence to harvest $\left(157.8\right.$ to $88.1 \mathrm{~cm}^{2} \mathrm{~g}^{-1} \mathrm{DW}$, calculated as the average of all treatments).

\section{Modelling crop response to $\mathbf{N}_{\min }$}

Figure 3A clearly shows that N nominal doses, supplied by fertilisers, and plant biomass accumulation were poorly correlated. This was consistent with: i) the poor correlation observed between $\mathrm{N}$ nominal dose and actual $\mathrm{N}_{\min }$ in the root zone (Figure $2 \mathrm{~B}$ ); and ii) the high variability of $Y$ in relation to the different growing conditions (i.e., Ta and Rad, Table 2 and Figure 1). Yield values were therefore divided by the PTU accumulated in each experiment, thus obtaining $\mathrm{Y}_{\text {PTU }}$, and then plotted versus $\mathrm{N}_{\min }$ (Eq. 2 for details).
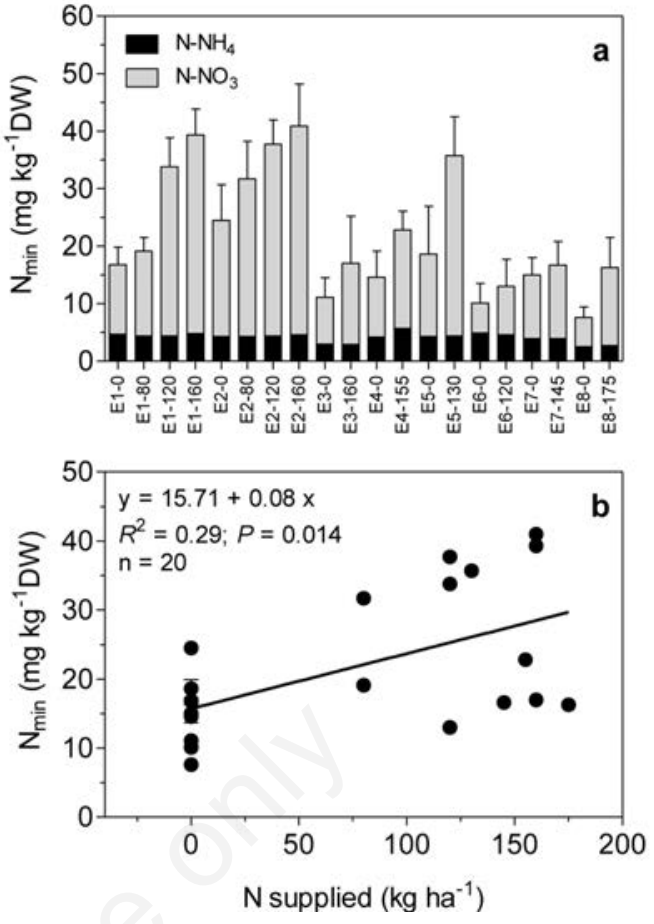

Figure 2. A) Ammonia (N-NH 4$)$, nitric $\left(\mathrm{N}-\mathrm{NO}_{3}\right)$ and total mineral $N$ concentration $\left(N_{\min }\right)$ in the root zone $(0-40 \mathrm{~cm}$ depth) averaged over the cultivation in the different experiments; each column represents the average of replicates $\pm S D$. B) Relationship between actual Nmin and the nominal doses of $\mathrm{N}$ supplied with fertilisers during the cultivation period; each point represents the average of replicates $\pm \mathrm{SE}$.

Table 3. Effect of different $\mathrm{N}$ supplies on dry weight and fresh weight accumulated at harvest. Each value represents the average of replicates $\pm \mathrm{SD}$.

\begin{tabular}{|c|c|c|c|}
\hline Treatment* & 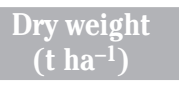 & $\begin{array}{l}\text { Fresh weight } \\
\qquad\left(\mathrm{tha}^{-1}\right)\end{array}$ & $\begin{array}{l}\text { Total N uptake } \\
\left(\mathrm{kg} \mathrm{ha}^{-1}\right)\end{array}$ \\
\hline E1-0 & $1.56 \pm 0.12$ cde & $17.69 \pm 1.32$ ab & $57.12 \pm 4.18$ c_f \\
\hline E1-80 & $1.88 \pm 0.30 \mathrm{abc}$ & $18.70 \pm 2.65$ ab & $64.91 \pm 10.39$ a_e \\
\hline E1-120 & $2.31 \pm 0.15 \mathrm{ab}$ & $21.69 \pm 1.95$ a & $78.41 \pm 5.18$ abc \\
\hline E1-160 & $2.43 \pm 0.19$ a & $21.60 \pm 1.30$ a & $87.37 \pm 6.66 \quad$ a \\
\hline E2-0 & $1.86 \pm 0.10 \mathrm{bc}$ & $17.46 \pm 1.31 \mathrm{abc}$ & $68.13 \pm 3.57 \quad \mathrm{a}_{-} \mathrm{e}$ \\
\hline E2-80 & $1.97 \pm 0.07 \mathrm{abc}$ & $18.16 \pm 0.62 a b$ & $78.16 \pm 4.07 \quad a b c$ \\
\hline $\mathrm{E} 2-120$ & $1.94 \pm 0.12 \mathrm{abc}$ & $18.43 \pm 1.01$ ab & $76.14 \pm 4.35 \quad \mathrm{a}_{-} \mathrm{d}$ \\
\hline E2-160 & $1.97 \pm 0.26 \mathrm{abc}$ & $17.66 \pm 2.44$ ab & $73.72 \pm 10.35 \quad$ a_d \\
\hline E3-0 & $0.97 \pm 0.27$ efg & $8.15 \pm 2.31$ efg & $33.01 \pm 4.92 \quad$ gh \\
\hline E3-160 & $1.18 \pm 0.30$ def & $10.66 \pm 2.78$ def & $45.65 \pm 9.34$ efg \\
\hline E4-0 & $1.50 \pm 0.21 \mathrm{c}_{-} \mathrm{f}$ & $12.65 \pm 1.93$ cde & $52.38 \pm 4.75 \quad \mathrm{~d}_{-} \mathrm{g}$ \\
\hline E4-155 & $1.99 \pm 0.11 \mathrm{abc}$ & $17.71 \pm 1.34$ ab & $81.62 \pm 4.38 \quad$ ab \\
\hline E5-0 & $1.46 \pm 0.02 \mathrm{c}_{-} \mathrm{f}$ & $14.75 \pm 0.60 \mathrm{bcd}$ & $57.82 \pm 6.51 \quad$ b_f \\
\hline E5-130 & $1.88 \pm 0.17 \mathrm{abc}$ & $17.83 \pm 1.72$ ab & $82.40 \pm 12.12 \quad$ a \\
\hline E6-0 & $0.25 \pm 0.04 \mathrm{~h}$ & $1.72 \pm 0.26 \mathrm{~h}$ & $6.28 \pm 1.27 \quad \mathrm{i}$ \\
\hline E6-120 & $1.13 \pm 0.58$ def & $6.87 \pm 3.51$ fgh & $27.29 \pm 5.15$ ghi \\
\hline E7-0 & $0.44 \pm 0.19$ fgh & $4.20 \pm 1.77$ gh & $14.48 \pm 3.22 \mathrm{hi}$ \\
\hline E7-145 & $0.95 \pm 0.11$ e_h & $10.40 \pm 0.81$ def & $38.55 \pm 7.81 \quad$ fgh \\
\hline E8-0 & $0.31 \pm 0.10 \mathrm{gh}$ & $2.17 \pm 0.92 \quad \mathrm{~h}$ & $6.55 \pm 2.42 \quad$ i \\
\hline E8-175 & $1.62 \pm 0.25 \mathrm{~cd}$ & $15.81 \pm 1.47 \mathrm{bcd}$ & $53.93 \pm 8.24 \quad c_{-} g$ \\
\hline Significance & $\mathrm{P}<0.001$ & $\mathrm{P}<0.001$ & $\mathrm{P}<0.001$ \\
\hline
\end{tabular}

*The abbreviations represent Experiment number-Dose of $\mathrm{N}$ supplied with fertilisers ( $\mathrm{kg} \mathrm{ha}^{-1}$, see Table 2); P-value for one-way ANOVA is reported. Different letters in each column represent significant differences according to Tukey's (HSD) test $(\mathrm{P} \leq 0.05)$. 
This expedient allowed the standardization of $Y$ in terms of different growing seasons with significant improvement in data analysis (Figure $3 \mathrm{~B}$ ). $\mathrm{Y}_{\text {PTU }}$ response to increasing $\mathrm{N}_{\min }$ was zero below a minimum threshold; then, it began to increase linearly with $\mathrm{N}_{\min }$ up to a maximum $\mathrm{Y}_{\mathrm{PTU}}\left(\mathrm{Y}_{\mathrm{PTU}}^{\mathrm{max}}\right)$, after which no significant variation was
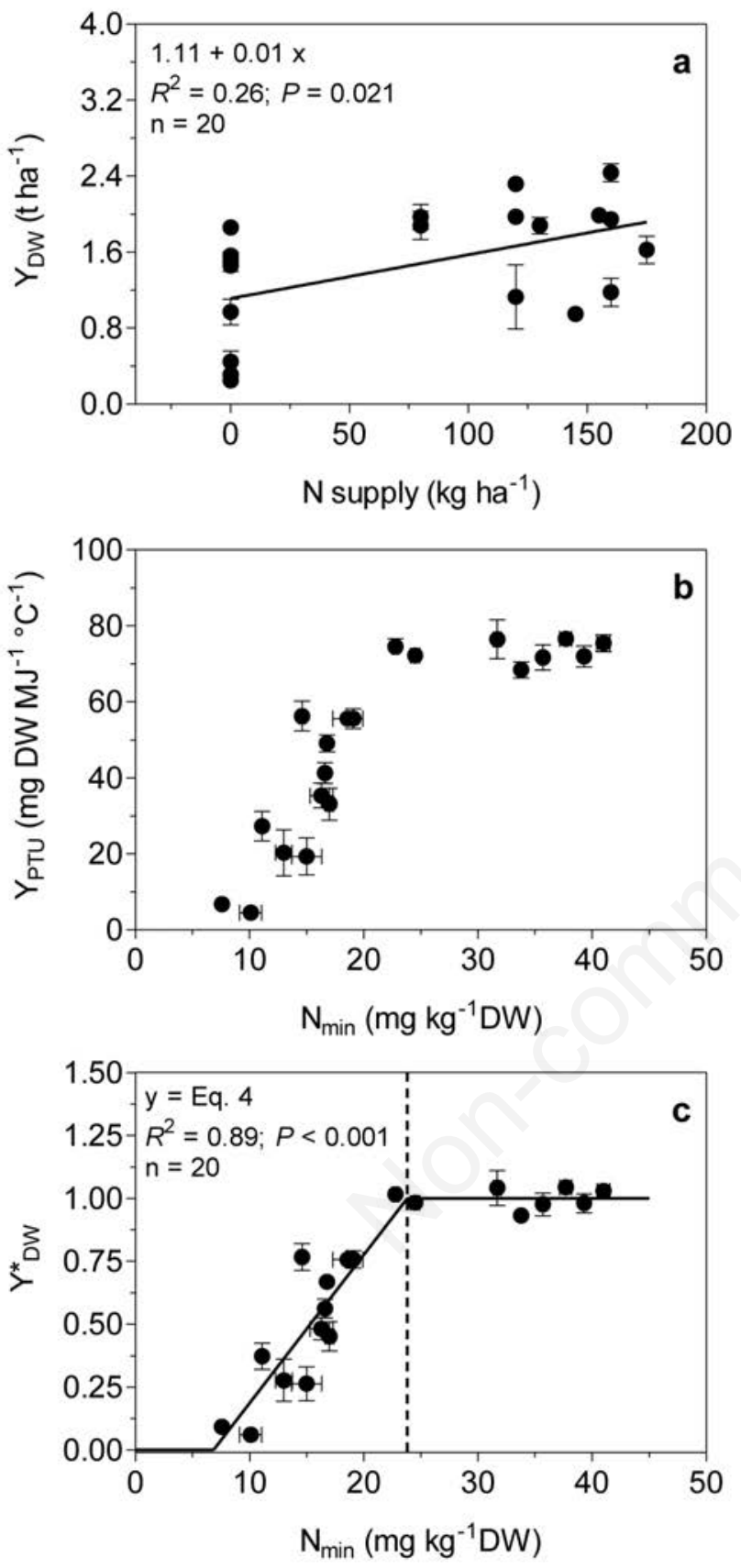

Figure 3. Relationship between: A) the nominal doses of $\mathrm{N}$ supplied with fertilisers during the cultivation period and the dry weight accumulated at harvest $\left(\mathrm{Y}_{\mathrm{DW}}\right)$; $\left.\mathrm{B}\right)$ the actual mineral nitrogen concentration in the root zone $\left(\mathrm{N}_{\min }\right)$ and crop photothermal use efficiency $\left(\mathrm{Y}_{\mathrm{PTU}}\right)$; or $\left.\mathrm{C}\right)$ its normalized values $\left(\mathrm{Y}^{*}{ }_{\mathrm{PTU}}\right)$, both calculated on the basis of dry weight accumulated at harvest. Each point represents the mean of replicates $( \pm S E)$. Continuous lines in panel $\mathrm{C}$ represent the model fitting the experimental data by Eq. 5; dotted lines represent the optimal value of $\mathrm{N}_{\min }\left(\mathrm{N}_{\mathrm{opt}}=23.44 \mathrm{~N}-\right.$ $\mathrm{NO}_{3} \mathrm{mg} \mathrm{kg}^{-1}$ ) for fresh-market spinach. observed. Data analysis produced ( $\left.\mathrm{Y}_{\mathrm{PTU}}^{\mathrm{max}}\right)$ values of 73.0 and 675.5 $\mathrm{mg} \mathrm{MJ} \mathrm{M}^{-1} \mathrm{C}^{-1}$, respectively for DW (Figure 3B) and $\mathrm{FW}$ (data not shown). These quantities were finally used for the normalization of the biomass datasets. The normalized $\mathrm{Y}_{\mathrm{PTU}}\left(\mathrm{Y}^{*}{ }_{\mathrm{PTU}}\right)$, which represents $\mathrm{Y}_{\mathrm{PTU}}$ as a proportion of $\left(\mathrm{Y}_{\mathrm{PTU}}^{\mathrm{max}}\right)$, was fitted using a segmented
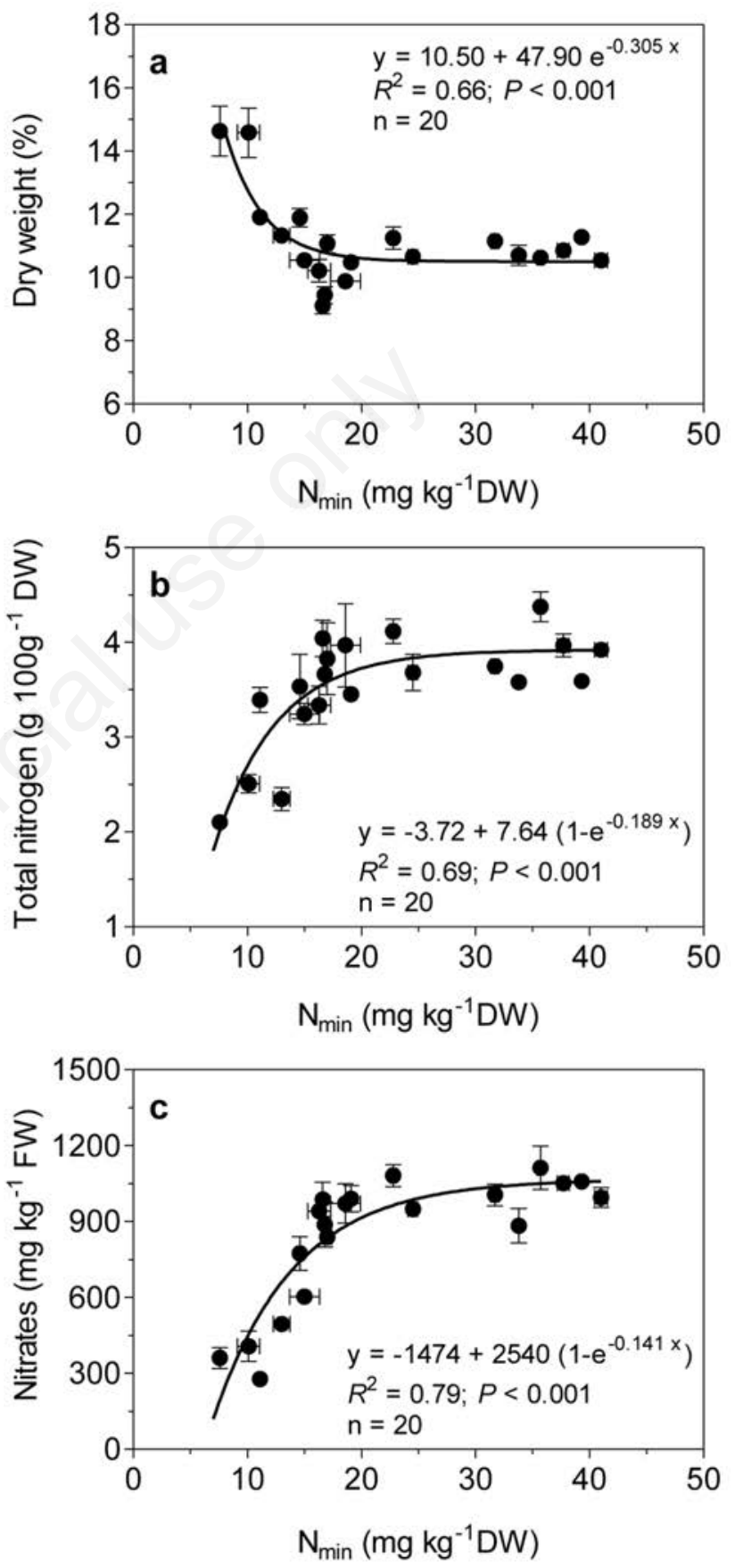

Figure 4. Relationship between the mineral nitrogen concentration in the root zone $\left(\mathrm{N}_{\min }\right)$ and $\left.\mathrm{A}\right)$ dry matter percentage; $\left.\mathrm{B}\right)$ total nitrogen concentration; and $\mathrm{C}$ ) leaf nitrate content of spinach tissues (shoot) as determined on samples collected at harvest. Each point represents the mean of replicates $( \pm$ SE). Continuous lines represent the non-linear equation proposed for data fitting. 
linear model (Figure 3C). Equation 5 significantly fitted $\mathrm{Y}_{\text {PTU, }}$, calculated for both $\mathrm{Y}_{\mathrm{DW}}$ (Figure 3C) and $\mathrm{Y}_{\mathrm{FW}}$ (data not shown), explaining 89 and $91 \%$ of the experimental variability, respectively $(\mathrm{P}<0.001)$. Model parameterization produced the following coefficients: i) an intercept (a; in Eq. 5) equal to -0.40 for $\mathrm{Y}^{*}$ Dw and -0.47 for $\mathrm{Y}_{\mathrm{FW}}$; ii) a slope (b; in Eq. 5), which represents the relative yield increase per $\mathrm{N}_{\min }$ unit, equal to 0.06 for both $\mathrm{Y}^{*}{ }_{\mathrm{DW}}$ and $\mathrm{Y}^{*}{ }_{\mathrm{DW}}$; iii) $\mathrm{N}_{0}$ equal to $6.85 \mathrm{mg} \mathrm{kg}^{-1}$ for $\mathrm{Y}^{*}{ }_{\mathrm{DW}}$ and $7.36 \mathrm{mg} \mathrm{kg}^{-1}$ for $\mathrm{Y}^{*}{ }_{\mathrm{FW}}$; iv) $\mathrm{N}_{\mathrm{opt}}$ equal to $23.80 \mathrm{mg} \mathrm{kg}^{-1}$ for $\mathrm{Y}^{*}$ DW and $23.08 \mathrm{mg} \mathrm{kg}^{-1}$ $\mathrm{Y}^{*}{ }_{\mathrm{FW}}$. Since no significant difference was found for the parameterisation of Eq. 5 using the two datasets, it could be concluded that the averaged values of $\mathrm{N}_{0}$ (i.e., $7.11 \mathrm{mg} \mathrm{kg}^{-1}$ ) and $\mathrm{N}_{\text {opt }}$ (i.e., 23.44 $\mathrm{mg} \mathrm{kg}^{-1}$ ) were representative for spinach crops. Basing on Eq. 1, the quantity of $\mathrm{N}_{\min }$ per surface unit corresponded to $\mathrm{N}_{\text {opt }}=140.0 \mathrm{~kg}$ ha $^{-1}$ and $\mathrm{N}_{0}=41.2 \mathrm{~kg} \mathrm{ha}^{-1}$.

\section{Plant tissue analyses and $\mathrm{N}$ uptake}

$\mathrm{N}_{\min }$ in the root zone significantly affected dry matter percentage in plant tissues. A one-phase exponential decay equation was fitted to experimental data, explaining $62 \%$ and $66 \%$ of the measurement variability for data averaged over the whole crop cycle (data not shown) or only at harvest (Figure 4A), respectively. At harvest, DW percentages were 9.1 and $14.6 \%$, for treatments with $\mathrm{N}_{\text {min }}$ above and below $\mathrm{N}_{\text {opt }}$, respectively. Data averaged during the whole crop cycle showed a more restricted range, from 9.6 to $12.9 \%$.

An opposite pattern was observed for tissue total $\mathrm{N}$ concentration. In this case, a one-phase exponential growth equation was fitted to experimental data explaining $63 \%$ and $69 \%$ of the measurement variability for data averaged over the whole crop cycle (data not shown) or only at harvest (Figure 4B).

At harvest, a positive relationship was found between $\mathrm{N}_{-} \mathrm{NO}_{3}{ }^{-}$ accumulation in plant tissues and $\mathrm{N}_{\min }$ in the root zone. However,

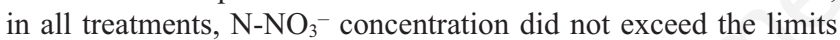
suggested by the European Food Safety Authority (EFSA) for this crop (Figure 4C). A one-phase exponential equation fitted the experimental data, showing a plateau value at $1030 \mathrm{~g} \mathrm{~kg}^{-1} \mathrm{FW}$ (Figure 4C).

Plant DW and tissue $\mathrm{N}$ content (Figure 4C) were combined to calculate the crop total $\mathrm{N}$ uptake at harvest (Table 3) and over the

\section{Number of true leaves}

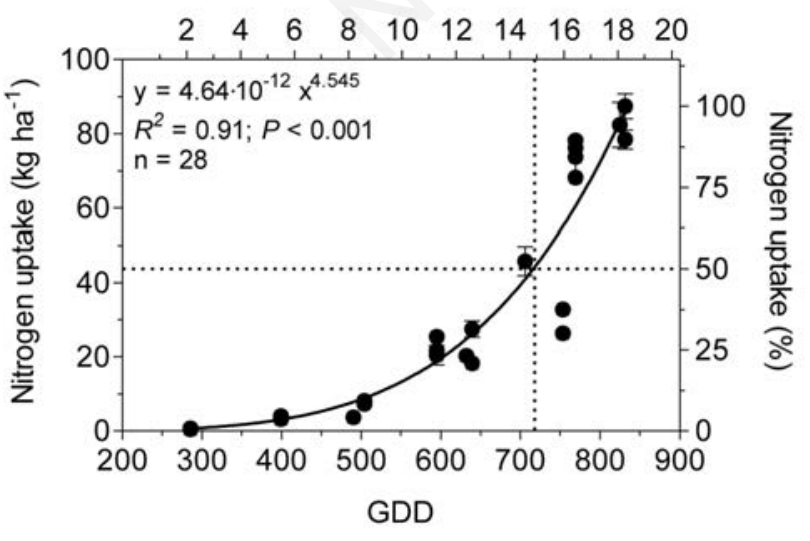

Figure 5. Relationship between crop nitrogen uptake and growing degree days (GDD) or number of true leaves. Dotted lines correspond to the growing phases at which $50 \%$ of the total $\mathrm{N}$ uptake occurs. Each point represents the mean of replicates $( \pm S E)$ of only the treatments (seven) grown under optimal N levels (see Figure 3C). cultivation cycle for each treatment. The latter data for spinach grown under optimal $\mathrm{N}$ conditions (i.e., excluding the treatments with $\mathrm{N}_{\min }$ below $\mathrm{N}_{\text {opt }}$ in Figure 3C) are reported in Figure 5 as a function of the GDD accumulated from sowing. The number of true leaves, which is also reported in Figure 5, is a further parameter that could be used to estimate the $\mathrm{N}$ uptake rate for spinach.

Data on leaf mineral content (Figure 6) and SPAD index (Figure 7) were pooled into two groups corresponding to $\mathrm{N}_{\min }$ values above $\mathrm{N}_{\text {opt }}\left(\mathrm{N}^{+}\right.$opt $)$or below $\mathrm{N}_{\text {opt }}\left(\mathrm{N}^{-}\right.$opt $)$. The concentrations of $\mathrm{N}, \mathrm{P}$ and $\mathrm{Mg}$ in plant tissues analysed at harvest were significantly

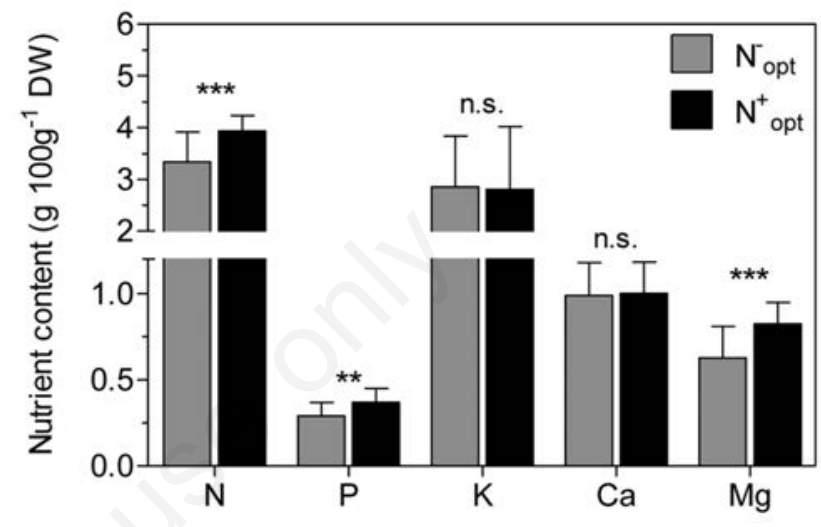

Figure 6. Concentration of total nitrogen $(\mathrm{N})$, phosphorus $(\mathrm{P})$, potassium $(\mathrm{K})$, calcium $(\mathrm{Ca})$ and magnesium $(\mathrm{Mg})$, determined at harvest, in plant tissues (shoot) of spinach grown under suboptimal $\left(\mathrm{N}^{-}{ }_{\text {opt }}\right)$ or optimal $\left(\mathrm{N}^{+}{ }_{\text {opt }}\right)$ concentration of $\mathrm{Nmin}$ in the root zone. Columns represents the average $( \pm S D)$ of treatments below $\left(\mathrm{N}^{-}{ }_{\text {opt }}\right)$ or above $\left(\mathrm{N}^{+}{ }_{\text {opt }}\right)$ the optimal threshold $\left(\mathrm{N}_{\text {opt }}\right)$ established for fresh-market spinach. Not significant (n.s.) or significant differences are also reported for $\mathrm{P} \leq 0.05\left({ }^{*}\right), 0.01\left(^{(*)}\right)$ and $0.001\left({ }^{* *}\right)$ according to one-way ANOVA.

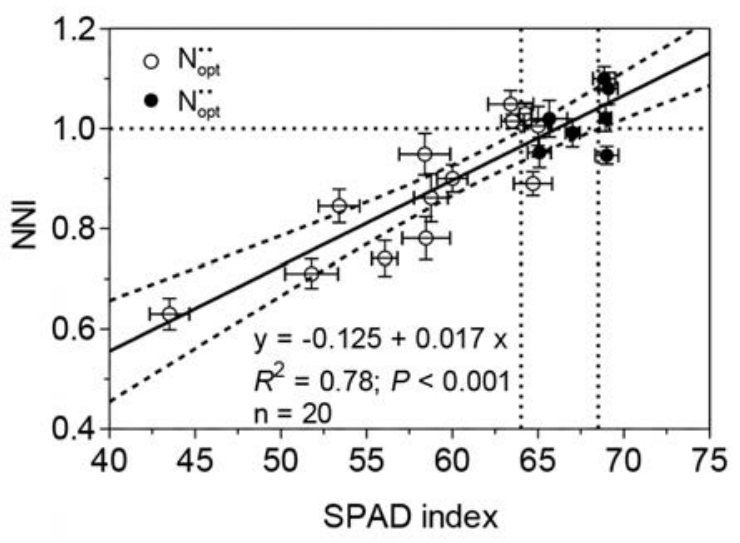

Figure 7. Linear regression between normalized nitrogen index (NNI) and SPAD index estimated by the averaged values of samples collected during the whole cultivation cycle in each treatment. Full and empty symbols represent values corresponding to plants grown under optimal $\left(\mathrm{N}^{+}{ }_{\text {opt }}\right)$ and suboptimal concentrations $\left(\mathrm{N}^{-}{ }_{\text {opt }}\right)$ of $\mathrm{Nmin}$ in the root zone, respectively. The horizontal dotted line represents NNI = 1 for spinach; vertical dotted lines represent the values of SPAD index within which NNI is optimal as calculated by the $95 \%$ confidence interval of the linear regression (dashed lines). Each point represents the mean of three replicates $( \pm S E)$. 
affected by suboptimal $\mathrm{N}_{\min }$ availability in the root zone (Figure 6).

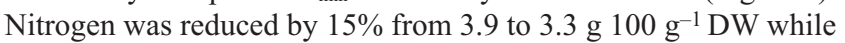
$\mathrm{P}$ and $\mathrm{Mg}$ were more severely affected with a reduction of 21 and $23 \%$, respectively. Conversely, no significant difference was observed at harvest for $\mathrm{K}$ and $\mathrm{Ca}$ tissue concentrations (Figure 6).

Suboptimal $\mathrm{N}_{\min }$ levels also affected the SPAD index that provides an indirect estimation of chlorophyll content. For this parameter, no significant difference was found between data averaged at harvest or during the whole crop cycle (ANOVA, $\mathrm{P}>0.05$ ) while a significant reduction was observed in $\mathrm{N}^{-}$opt treatments compared with $\mathrm{N}^{+}$opt treatments. Figure 7 shows the relationship between NNI and SPAD index. The linear regression model significantly fitted the measured data, explaining $78 \%$ of the experimental variability. The collected data suggest that values of SPAD index between 64.0 and 68.5 would be optimal for savoy spinach to avoid $\mathrm{N}$ deficiency or excess. This range was calculated on the basis of the confidence interval resulting from the linear regression analysis (Figure 7).

\section{Discussion}

\section{Yield response curve to $N_{\min }$ concentration in the root zone}

Very poor correlations between the nominal dose of $\mathrm{N}$, applied through mineral fertilisers, and the actual $\mathrm{N}_{\min }$ concentration in the root zone or the harvested biomass were found in this work. In some cases (i.e., treatments E1-0 and E2-0; Table 3) high Y occurred without any $\mathrm{N}$ supply, since a sufficient (optimal) level of $\mathrm{N}_{\min }$ was already present in the root zone before sowing, which supported adequately plant $\mathrm{N}$ nutrition throughout the whole cultivation cycle. Similar results have been obtained in previous studies with spinach (Gülser, 2005; Stagnari et al., 2007). Defining the relationship between crop $\mathrm{Y}$ and $\mathrm{N}_{\min }$ appears therefore of fundamental importance for a balanced $\mathrm{N}$ supply whereby both economic and environmental sustainability of the crop can be maximized (Schroder et al., 2000; Cui et al., 2008; Bai et al., 2013).

The harvest time varied widely among the different experiments. Spinach was harvested when the plants achieved 16 to 22 leaves, according to the market requirement and the weather (for example, rainfalls can delay the harvest). Furthermore, the quite different climate conditions (mainly Ta and Rad) during the years of observation caused a large variability in terms of plant growth. Crop Y was therefore standardized by PTU thus obtaining comparable data (i.e., $\mathrm{Y}_{\mathrm{PTU}}$ ) collected over different growing seasons. The use of $Y_{\text {PTU }}$ was successfully applied by other authors to assess differences in the theoretical $\mathrm{Y}$ of several crops grown in different regions (Hou et al., 2012).

For modelling crop response to soil nutrient concentration, several authors fitted crop Y using linear-plateau models (Reid, 2002; Cui et al., 2008; Bai et al., 2013; Magán et al., 2008) as was done in the present work by Eq. 5. On the other hand, many other authors described the response of different crops to $\mathrm{N}_{\min }$ or $\mathrm{N}$ fertiliser dose using non-linear equations (Thornley and Johnson, 1990; Van Noordwijk and Wadman, 1992; Reid, 2002; Milne et al., 2012). Therefore, the preliminary data analysis in the present work included non-linear models consisting in quadratic and hyperbolic functions as suggested by Thornley and Johnson (1990). However, the resulting determination coefficients (in the range of 0.83-0.86), or other error performance indices, were close to the ones achieved with the proposed linear model or even worse. The same was obtained for the other observed statistical parameters.

With respect to non-linear models, Eq. 5 has the advantage of producing an unequivocal value for $\mathrm{N}_{\text {opt }}$; in contrast, the use of non-linear equations may lead to higher uncertainty in the identification of $\mathrm{N}_{\text {opt }}$. The $\mathrm{N}_{\mathrm{opt}}$ value found in the present study $(23.44 \mathrm{mg}$ $\mathrm{kg}^{-1}$ ) for spinach was quite similar to others reported in literature for different crops. In fact, optimal $\mathrm{N}_{\min }$ in the root zone have been found in the range of $16-30 \mathrm{mg} \mathrm{kg}^{-1}$ dry soil for corn (Cui et al., 2008; Peng et al., 2013), 20-21 mg kg-1 for wheat (Bundy and Andraski, 2004), 20-30 $\mathrm{mg} \mathrm{kg}^{-1}$ for potato (Doll et al., 1971), 24 $\mathrm{mg} \mathrm{kg}^{-1}$ for cabbage (Heckman et al., 2002), and 20-24 mg kg-1 for celery and lettuce (Hartz et al., 2000; Bottoms et al., 2012).

\section{Crop quality response to $\mathbf{N}_{\min }$ concentration in the root zone}

Nitrate accumulation in spinach leaves is due to many factors depending on both environmental growth conditions (e.g., temperature, radiation, $\mathrm{N}$ fertilisation management) and plant-specific characteristics (e.g., nitrate reductase activity, leaf age) (Lasa et al., 2001; Chen et al., 2004; Gülser, 2005; Stagnari et al., 2007). High availability of $\mathrm{N}_{\min }$ in the root zone indeed promotes nitrates and total $\mathrm{N}$ accumulation in leaves. Similar results have been observed in other leafy vegetables, such as romaine and red-oak leaf lettuce (Di Gioia et al., 2017). However, the tissue nitrate content observed in this work was within the limits suggested by EFSA (2008) for spinach. It was likely due to the quite low plant density and to the $\mathrm{N}$ level in the soil that was not too much exceeding $\mathrm{N}_{\text {opt }}$ (maximum $\mathrm{N}_{-} \mathrm{NO}_{3}$ value was $36 \mathrm{mg} \mathrm{kg}^{-1}$, recorded in the treatment E2-160).

Tissue content of other plant mineral nutrients responded differently to $\mathrm{N}_{\min }$ treatments depending on the nutrient element. Literature on spinach is quite heterogeneous with regard to the relationship between tissue content of plant mineral nutrients and $\mathrm{N}_{\text {min }}$ in the root zone. In several studies, positive correlations between $\mathrm{N}, \mathrm{Ca}$, or $\mathrm{Mg}$ and $\mathrm{N}_{\min }$ have been reported (Lefsrud et al., 2007; Staganari et al., 2007). However, contrasting findings have been reported for $\mathrm{P}$ or $\mathrm{K}$ that were found to increase (Stagnari et al., 2007), to be constant (Lefsrud et al., 2007, only K) or even to decrease (Gülser, 2005, only P) by increasing $\mathrm{N}_{\min }$ in the root zone. A significant positive correlation between $\mathrm{P}$ or $\mathrm{Mg}$ and $\mathrm{N}_{\min }$ in the root zone ( $\mathrm{P}<0.001, R=0.70$ or 0.71 , respectively) was observed in this work, as previously reported by other authors (Lefsrud et al., 2007; Stagnari et al., 2007). On the other hand, no significant correlation was found between $\mathrm{K}$ or $\mathrm{Ca}$ tissue content and $\mathrm{N}$ treatments, in agreement with Gülser (2005).

Increasing $\mathrm{N}_{\min }$ in the root zone led to an enhanced blade colour. This is a relevant reference extrinsic characteristic, much appreciated by consumers of fresh-market spinach. The SPAD index was significantly lower in $\mathrm{N}^{-}$opt treatments, in which plants were grown under suboptimal nutritional conditions. SPAD index is significantly correlated to leaf $\mathrm{N}$ and leaf chlorophyll concentration (Schepers et al., 1992), on which spinach colour depends mostly. Leaf chlorophyll concentration has been found positively correlated to $\mathrm{N}_{\min }$ in the root zone in spinach (Lefsrud et al., 2007), and to leaf $\mathrm{N}$ and $\mathrm{Mg}$ concentration in many species (Shaahan et al., 1999) as also observed in this work.

The use of chlorophyll meters, such as the SPAD, could be not reliable to estimate on-time crop $\mathrm{N}$ requirement because of possible delays between the nutrient status of the root zone and its effects on plants (Westerveld et al., 2003; Wu et al., 2007). Nevertheless, the information provided by these tools and other optical sensors may be valuable if coupled with data on soil com- 
position obtained through either laboratory analyses or easy-to-use and rapid methods available at farm level (Hartz et al., 2000; Maggini et al., 2010; Thompson et al., 2017).

\section{Implementation of the results for improving spinach $\mathbf{N}$ fertilisation management}

Growers usually adopt very simple $\mathrm{N}$ fertilisation plans for fresh-market spinach. In Tuscany (Italy), where the experiment took place, they usually apply from 120 to $175 \mathrm{~kg} \mathrm{ha}^{-1} \mathrm{~N}$ for each growing cycle, often as fixed reference dosages without pre-sowing soil analyses. This fertilisation approach is quite robust and effective from the growers' point-of-view. In common practice, the application of $120 \mathrm{~kg} \mathrm{ha}^{-1} \mathrm{~N}$ to a crop like savoy spinach, which takes up from roughly 60 to $75 \%$ of the above quantity, consists in a sort of insurance against possible low soil $\mathrm{N}$ concentration and rainy periods that could hinder $\mathrm{N}$ top dressing applications. Obviously, this approach contributes to $\mathrm{N}$ loss phenomena related to excess $\mathrm{N}$ in the root zone and may reduce produce quality. In the above scenario, the risk for high crop environmental impact and production costs increases drastically (Massa et al., 2013).

According to our results, the presence of roughly $23 \mathrm{mg} \mathrm{kg}^{-1}$ of $\mathrm{N}_{\min }$ in the soil is enough for a regular spinach growth and development without any yield and/or quality reduction. An ideal management of $\mathrm{N}$ fertilisation would consist in the supply of small fertiliser amounts at high frequency to keep $\mathrm{N}_{\min }$ concentration close to $\mathrm{N}_{\text {opt}}$, as in fertirrigated crops. Nevertheless, a similar fertiliser application plan would not be sustainable for winter spinach under open-field operative conditions from both the agronomic and the economic point of view. Based on the crop $\mathrm{N}$ uptake curve reported in Figure 5, 50\% of the total $\mathrm{N}$ absorbed by spinach is concentrated in the last part of the growing cycle (the last three to five weeks between the 13-15 true-leaf phase and harvest time). Similar results have been reported for other leafy vegetables such as lettuce (Bottoms et al., 2012). Therefore, when $\mathrm{N}$ fertilisers have to be applied in advance, data reported in Figure 5 must be carefully taken into account in terms of doses and distribution frequency to avoid excess $\mathrm{N}$ supply when plants are not ready to take this element up.

The results obtained in this work could be implemented for advanced $\mathrm{N}$ fertilisation strategies, which are based on a pre-sowing $\mathrm{N}_{\min }$ soil analysis followed by $\mathrm{N}_{\min }$ monitoring in the root zone (Thompson et al., 2017). At the pre-sowing stage, if the soil $\mathrm{N}_{\min }$ is lower than $\mathrm{N}_{\mathrm{opt}}$, a base fertilisation is necessary. After sowing, topdressing fertilisations will then be necessary only if the level of $\mathrm{N}_{\min }$ in the root zone drops below $\mathrm{N}_{\text {opt. }}$. Nowadays, soil $\mathrm{N}_{\min }$ can be easily monitored at farm level by using quick tests that are faster, simpler, and cheaper than the conventional laboratory analyses (Hartz et al., 2000; Maggini et al., 2010; Incrocci et al., 2017). For example, this approach has been validated for the fertilisation plan of lettuce and celery in California (Hartz et al., 2000), and for cabbage in North America (Heckman et al., 2002) or in The Netherlands (Everaarts and de Moel, 1998).

Furthermore, the model calibrated in the present work (Eq. 5) can be implemented in decision support systems for the precise nutrient management of spinach. In addition to the estimation of $\mathrm{N}_{\text {opt }}$, the implementation of Eq. 5 in decision support systems can be useful to simulate spinach growth, as a function of $\mathrm{N}_{\min }$ in the root zone, and eventually calculate the dose and distribution fre- quency of $\mathrm{N}$ fertilisers based on real plant needs.

The relationship between NNI and SPAD index provides additional information for the precise management of $\mathrm{N}$ nutrition in spinach using optical sensors, as previously reported for other vegetable crops (Padilla et al., 2015; Thompson et al., 2017; Incrocci et al., 2017). Spinach for fresh market is harvested at early growth stage. We observed that, within this growing period, $\mathrm{N}$ tissue concentration did not vary significantly; it was therefore possible to find a significant correlation between SPAD index and NNI using data averaged over the whole cultivation cycle. On the other hand, much higher variability was observed for other vegetable crops in different growing periods (Padilla et al., 2014, 2015).

As observed in the present work, SPAD values lower than 64.0 would imply $\mathrm{N}$ deficiency with reduced $\mathrm{Y}$ for fresh-market spinach. Lower values were observed for open-field processing (Canali et al., 2014) and greenhouse-grown spinach (Liu et al., 2006; Muchecheti et al., 2016). However, the threshold values reported in Figure 7 (in the range of 64.0-68.5) were assessed in this work for the first time for NNI-based quick $\mathrm{N}$ monitoring in fresh-market spinach grown under open-field Mediterranean climate conditions. The combination of soil analyses and optical leaf sensors, like the SPAD used in this study, indeed appears of great interest for the optimized management of $\mathrm{N}$ fertilisation in vegetable crops (Incrocci et al., 2017).

\section{Conclusions and remarks}

Meaningful relationships between crop yield or quality and mineral nitrogen availability in the root zone are reported in this work for fresh-market spinach. A linear-plateau model significantly represented the yield response to $\mathrm{N}$ concentration in the root zone. The adopted model was successful in determining an optimal threshold value (i.e., $\mathrm{N}_{\mathrm{opt}}$ ) of $23.44 \mathrm{mg} \mathrm{kg}^{-1} \mathrm{DW}\left(140.0 \mathrm{~kg} \mathrm{ha}^{-1}\right.$ in our experimental conditions) to be maintained in the root zone for efficient $\mathrm{N}$ fertilisation plans of this crop.

Plant tissue analyses supported the hypothesis that there is no reason to exceed $\mathrm{N}_{\text {opt }}$ in the root zone since above this threshold most of plant tissue characteristics tend to be unaffected. In contrast, plants grown under suboptimal levels of $\mathrm{N}$ in the root zone (i.e., below $\mathrm{N}_{\mathrm{opt}}$ ) show a reduced yield and tissue content of mineral nutrients and SPAD index, which imply that $\mathrm{N}_{\text {opt }}$ must be maintained in the root zone to obtain high yield and quality. Maintaining the suggested conditions in the root zone may therefore significantly improve the environmental and economic sustainability of the crop.

The use of optical sensors (e.g., the SPAD by Minolta used in the present work) can be helpful for growers to check quickly the $\mathrm{N}$ nutritional status of the crop; SPAD index higher than 64.0 would ensure optimal $\mathrm{N}$ nutrition in fresh-market spinach. The combined monitoring of the root zone and crop canopy therefore appears a strategy worth exploring for the correct management of $\mathrm{N}$ fertilisers in this crop. The results reported in this paper can be implemented in protocols, algorithms and decision support systems for the optimized $\mathrm{N}$ fertilisation of fresh-market spinach. 


\begin{tabular}{|c|c|c|}
\hline \multicolumn{3}{|c|}{ Abbreviations } \\
\hline Symbol & Description & Units \\
\hline $\mathrm{CV}$ & Coefficient of variation & \\
\hline DW & Dry weight & $\mathrm{tha}^{-1}$ \\
\hline E & Experiment & \\
\hline FW & Fresh weight & $\mathrm{tha}^{-1}$ \\
\hline GDD & Growing degree days or thermal time & ${ }^{\circ} \mathrm{C}$ \\
\hline LAI & Leaf area index & \\
\hline $\mathrm{N}_{0}$ & $\begin{array}{l}\text { Soil mineral nitrogen concentration below which } \\
\text { yield is zero } \mathrm{m} \mathrm{kg}^{-1}, \mathrm{~kg} \mathrm{ha}^{-1}\end{array}$ & \\
\hline $\mathrm{n}_{\text {Leaves }}$ & Number of true leaves & $\mathrm{n}$ \\
\hline $\mathrm{N}^{-}{ }_{\text {opt }}$ & Pool of treatments below $\mathrm{N}_{\text {opt }}$ & \\
\hline $\mathrm{N}^{+}{ }_{\text {opt }}$ & Pool of treatments above $\mathrm{N}_{\mathrm{opt}}$ & \\
\hline $\mathrm{N}_{\min }$ & Total mineral nitrogen in the root zone & $\begin{array}{l}\mathrm{mg} \mathrm{kg}^{-1} \mathrm{DW} \text { or } \\
\mathrm{kg} \mathrm{ha}^{-1}\end{array}$ \\
\hline $\mathrm{N}_{\mathrm{opt}}$ & $\begin{array}{l}\text { Optimal nitrogen concentration to be maintained } \\
\text { in the root zone for spinach }\end{array}$ & $\mathrm{mg} \mathrm{kg}^{-1}, \mathrm{~kg} \mathrm{ha}^{-1}$ \\
\hline NNI & Nitrogen nutrition index & \\
\hline PTU & Photothermal units & $\mathrm{MJ} \mathrm{m}{ }^{-2}{ }^{\circ} \mathrm{C}^{-1}$ \\
\hline Rad & Global radiation & $\mathrm{MJ} \mathrm{m}^{2} \mathrm{day}^{-1}$ \\
\hline SD & Standard deviation & \\
\hline SE & Standard error & \\
\hline $\mathrm{Ta}$ & Air temperature & ${ }^{\circ} \mathrm{C}$ \\
\hline $\mathrm{Tb}$ & Base air temperature & ${ }^{\circ} \mathrm{C}$ \\
\hline $\mathrm{Y}$ & Crop yield & $\mathrm{tha}^{-1}$ \\
\hline $\mathrm{Y}_{\mathrm{PTU}}$ & Photothermal use efficiency or potential yield & $\mathrm{t} \mathrm{MJ}^{-1} \mathrm{~m}^{-2}{ }^{\circ} \mathrm{C}^{-1}$ \\
\hline$Y_{\text {PTU }}^{\max }$ & $\begin{array}{l}\text { Maximum photothermal use efficiency or } \\
\text { potential yield }\end{array}$ & $\mathrm{t} \mathrm{MJ}^{-1} \mathrm{~m}^{-2}{ }^{\circ} \mathrm{C}^{-1}$ \\
\hline $\mathrm{Y}^{*}{ }_{\mathrm{PTU}}$ & $\mathrm{Y}_{\mathrm{PTU}} / \mathrm{Y}_{\mathrm{PTU}}^{\max }$ & \\
\hline
\end{tabular}

\section{References}

Agnoli C, Baroni L, Bertini I, Ciappellano S, Fabbri A, Papa M, Pellegrini N, Sbarbati R, Scarino ML, Siani V, Sieri S, 2017. Position paper on vegetarian diets from the working group of the Italian Society of Human Nutrition. Nutr. Metab. Cardiovasc. Dis. 27:1037-52.

Bai Z, Li H, Yang X, Zhou B, Shi X, Wang B, Li D, Shen J, Chen Q, Qin W, Oenema O, Zhang F, 2013. The critical soil P levels for crop yield, soil fertility and environmental safety in different soil types. Plant Soil 372:27-37.

Biemond H, Vos J, Struik PC, 1996. Effects of nitrogen on accumulation and partitioning of dry matter and nitrogen of vegetables.3. Spinach. Neth. J. Agr. Sci. 44:227-39.

Bottoms TG, Smith RF, Cahn MD, Hartz TK, 2012. Nitrogen requirements and $\mathrm{N}$ status determination of lettuce. HortSci. 47:1768-74.

Bryan NS, Loscalzo J, 2011. Nitrite and nitrate in human health and disease. Humana Press, New York, NY, USA.

Bundy LG, Andraski TW, 2004. Diagnostic tests for site-specific nitrogen recommendations for winter wheat. Agron. J. 96:608-14.

Canali S, Diacono M, Ciaccia C, Masetti O, Tittarelli F, Montemurro F, 2014. Alternative strategies for nitrogen fertilization of overwinter processing spinach (Spinacia oleracea L.) in Southern Italy. Eur. J. Agr. 54:47-53.

Cataldo DA, Haroon M, Schrader LE, Youngs VL, 1975. Rapid colorimetric determination of nitrate in plant-tissue by nitration of salicylic-acid. Commun. Soil Sci. Plant Anal. 6:71-80.

Cavaiuolo M, Ferrante A, 2014. Nitrates and glucosinolates as strong determinants of the nutritional quality in rocket leafy salads. Nutrients 6:1519-38.

Chen BM, Wang ZH, Li SX, Wang GX, Song HX, Xi-Na W, 2004. Effects of nitrate supply on plant growth, nitrate accumulation, metabolic nitrate concentration and nitrate reductase activity in three leafy vegetables. Plant Sci. 167:635-43.

Cui Z, Chen X, Miao Y, Zhang F, Sun Q, Schroder J, Zhang H, Li J, Shi L, Xu J, 2008. On-farm evaluation of the improved soil Nmin-based nitrogen management for summer maize in North China Plain. Agron. J. 100:517-25.

Di Gioia F, Gonnella M, Buono V, Ayala O, Santamaria P, 2017. Agronomic, physiological and quality response of romaine and red oak-leaf lettuce to nitrogen input. Ital. J. Agron. 12:47-58.

Doll EC, Christenson DR, Wolcott AR, 1971. Potato yields as related to nitrate levels in petioles and soils. Am. Potato J. 48:105-12.

Dordas C, 2008. Role of nutrients in controlling plant diseases in sustainable agriculture. A review. Agron. Sustain. Dev. 28:33-46.

EFSA, 2008. Nitrate in vegetables - Scientific Opinion of the Panel on Contaminants in the Food chain. EFSA J. 1-79.

Everaarts AP, De Moel CP, 1998. The effect of nitrogen and the method of application on yield and quality of white cabbage. Eur. J. Agr. 9:203-11.

Gülser R, 2005. Effects of ammonium sulphate and urea on $\mathrm{NO}_{3}{ }^{-}$ and $\mathrm{NO}_{2}{ }^{-}$accumulation, nutrient contents and yield criteria in spinach. Sci. Hortic. 106:330-40.

Hartz TK, Bendixen WE, Wierdsma L, 2000. The value of presidedress soil nitrate testing as a nitrogen management tool in irrigated vegetable production. HortSci. 35:651-6.

Heckman JR, Morris T, Sims JT, Sieczka JB, Krogmann U, Nitzsche P, Ashley R, 2002. Pre-sidedress soil nitrate test is effective for fall cabbage. HortSci. 37:113-7.

Hou Y, Hou G, Qi H, Chen C, Li X, Zhao M, Dong S, 2012. Analysis of photothermic resource use efficiency and potential increases in crop yields in high-yielding regions of eastern Asia. Aust. J. Crop Sci. 6:784-92.

Incrocci L, Massa D, Pardossi A, 2017. New trends in the fertigation management of irrigated vegetable crops. Horticulturae $3: 37$.

Jenni S, Cloutier DC, Bourgeois G, Stewart KA, 1996. A heat unit model to predict growth and development of muskmelon to anthesis of perfect flowers. J. Am. Soc. Hort. Sci. 121:274-80.

Kempers AJ, Kok CJ, 1989. Re-examination of the determination of ammonium as the indophenol blue complex using salicylate. Anal. Chim. Acta 221:147-55.

Lasa B, Frechilla S, Lamsfus C, Aparicio-Tejo PM, 2001. The sensitivity to ammonium nutrition is related to nitrogen accumulation. Sci. Hortic. 91:143-52.

Lefsrud MG, Kopsell DA, Kopsell DE, 2007. Nitrogen levels influence biomass, elemental accumulations, and pigment concentrations in spinach. J. Plant Nutr. 30:171-85.

Liu Y-J, Tong Y-P, Zhu Y-G, Ding H, Smith FA, 2006. Leaf chlorophyll readings as an indicator for spinach yield and nutritional quality with different nitrogen fertilizer applications. J. Plant Nutr. 29:1207-17.

Lombardo S, Restuccia C, Muratore G, Barbagallo RN, Licciardello F, Pandino G, Scifò GO, Mazzaglia A, Ragonese F, Mauromicale G, 2017. Effect of nitrogen fertilisation on the overall quality of minimally processed globe artichoke heads. J. Sci. Food Agric. 97:650-8.

Magán JJ, Gallardo M, Thompson RB, Lorenzo P, 2008. Effects of salinity on fruit yield and quality of tomato grown in soil-less culture in greenhouses in Mediterranean climatic conditions. Agric. Water Manage. 95:1041-55.

Maggini R, Carmassi G, Incrocci L, Pardossi A, 2010. Evaluation of quick test kits for the determination of nitrate, ammonium and phosphate in soil and in hydroponic nutrient solutions. Agrochimica 54:331-41. 
Massa D, Incrocci L, Pardossi A, Delli Paoli P, Battilani A, 2013. Application of a decision support system for increasing economic and environmental sustainability of processing tomato cultivated in Mediterranean climate. Acta Hortic. 971:51-8.

Milne AE, Webster R, Ginsburg D, Kindred D, 2012. Spatial multivariate classification of an arable field into compact management zones based on past crop yields. Comput. Electron. Agric. 80:17-30.

Muchecheti F, Madakadze C, Soundy P, 2016. Leaf chlorophyll readings as an indicator of nitrogen status and yield of spinach (Spinacia oleracea L.) grown in soils amended with Luecaena leucocephala prunings. J. Plant Nutr. 39: 539-61.

Noonan SC, 1999. Oxalate content of foods and its effect on humans. Asia Pac. J. Clin. Nutr. 8:64-74.

Olsen SR, Sommers EL, 1982. Phosphorus. In: A.L. Page (ed.) Methods of Soil Analysis. Madison, Wisconsin, USA, pp 403-30.

Padilla FM, Peña-Fleitas MT, Gallardo M, Thompson RB, 2015. Threshold values of canopy reflectance indices and chlorophyll meter readings for optimal nitrogen nutrition of tomato. Ann. Appl. Biol. 166: 271-85.

Padilla FM, Teresa Peña-Fleitas M, Gallardo M, Thompson RB, 2014. Evaluation of optical sensor measurements of canopy reflectance and of leaf flavonols and chlorophyll contents to assess crop nitrogen status of muskmelon. Eur. J. Agr. 58:39-52.

Peng Y, Yu P, Li X, Li C, 2013. Determination of the critical soil mineral nitrogen concentration for maximizing maize grain yield. Plant Soil 372:41-51.

Reid JB, 2002. Yield response to nutrient supply across a wide range of conditions. 1. Model derivation. Field Crops Res. 77:161-71.

Robertson GP, Vitousek PM, 2009. Nitrogen in agriculture: Balancing the cost of an essential resource. Ann. Rev. Environ. Res. 34:97-125.

Rodriguez-Hidalgo S, Artes-Hernandez F, Gomez PA, Fernandez JA, Artes F, 2010. Quality of fresh-cut baby spinach grown under a floating trays system as affected by nitrogen fertilisation and innovative packaging treatments. J. Sci. Food Agric. 90:1089-97.

Santamaria P, Elia A, Serio F, Todaro E, 1999. A survey of nitrate and oxalate content in fresh vegetables. J. Sci. Food Agric. 79:1882-8.

Schepers JS, Francis DD, Vigil M, Below FE, 1992. Comparison of corn leaf nitrogen concentration and chlorophyll meter readings. Commun. Soil Sci. Plant Anal. 23:2173-87.

Schroder JJ, Neeteson JJ, Oenema O, Struik PC, 2000. Does the crop or the soil indicate how to save nitrogen in maize production? Reviewing the state of the art. Field Crops Res. 66:151-64.

Shaahan MM, El-Sayed AA, Abou El-Nour EAA, 1999. Predicting nitrogen, magnesium and iron nutritional status in some perennial crops using a portable chlorophyll meter. Sci. Hortic. $82: 339-48$

Stagnari F, Di Bitetto V, Pisante M, 2007. Effects of N fertilizers and rates on yield, safety and nutrients in processing spinach genotypes. Sci. Hortic. 114:225-33.

The Council of the European Communities, 1991. Council Directive of 12 December 1991 concerning the protection of waters against pollution caused by nitrates from agriculture sources (91/676/EEC). Off. J. Eur. Commun. L375.

The Council of the European Community, 2006. Regulation no. $1881 / 2006$.

Thompson RB, Incrocci L, Voogt W, Pardossi A, Magán JJ, 2017. Sustainable irrigation and nitrogen management of fertigated vegetable crops. Acta Hortic. 1150:363-78.

Thornley JHM, Johnson IR, 1990. Plant and crop modelling. A mathematical approach to plant and crop physiology. Clarendon Press, Oxford, UK.

Van Noordwijk M, Wadman WP, 1992. Effects of spatial variability of nitrogen supply on environmentally acceptable nitrogen fertilizer application rates to arable crops. Neth. J. Agric. Sci. 40:51-72.

Wang ZH, Li SX, 2004. Effects of nitrogen and phosphorus fertilization on plant growth and nitrate accumulation in vegetables. J. Plant Nutr. 27:539-56.

Westerveld SM, McDonald MR, McKeown AW, Scott-Dupree $\mathrm{CD}, 2003$. Optimum nitrogen fertilization of summer cabbage in Ontario. Acta Hortic. 627:211-5.

Wolfe DW, Albright LD, Wyland J, 1989. Modeling row cover effects on microclimate and yield. I. Growth response of tomato and cucumber. J. Am. Soc. Hort. Sci. 114:562-8.

Wu JD, Wang D, Rosen CJ, Bauer ME, 2007. Comparison of petiole nitrate concentrations, SPAD chlorophyll readings, and QuickBird satellite imagery in detecting nitrogen status of potato canopies. Field Crops Res. 101:96-103.

Zhang Y, Lin X, Zhang Y, Shao JZ, Du S, 2005. Effects of nitrogen levels and nitrate/ammonium ratios on oxalate concentrations of different forms in edible parts of spinach. J. Plant Nutr. 28: 2011-25.

Zhou M, Butterbach-Bahl K, 2014. Assessment of nitrate leaching loss on a yield-scaled basis from maize and wheat cropping systems. Plant Soil 374:977-91. 